\title{
Luther and Medieval Mysticism in the Context of Recent Historiography
}

\author{
WERNER O. PACKULL
}

Rarely satisfied with a mere reinterpretation of "historical facts," reflective historical scholarship interacts with past and contemporary points of view. The recent book by Bengt Hoffman ${ }^{1}$ illustrates this point. In his reexamination of Luther and the mystical, Hoffman attempts to revise prevailing interpretations in the light of the "contemporary revolt against reason" and the rediscovery of "human transcendence" in "charismatic renewal." The effort is not without merit. The majority of German Luther scholars for once escape the charge of rolling their eyeballs and engaging in nonsensical God-talk! Indeed, much of Hoffman's energy is directed against the influence of rationalism - scholastic and scientific ${ }^{2}$ - on previous historiography. On his part, Hoffman attempts to illustrate that Luther's theological insights were rooted in the mystical experience of the numinous. He concludes that in spite of a different "nomenclature" Luther and his mystical predecessors, John Tauler and the author of the Theologia Deutsch, reckoned with a similar substantive connection between the human and the divine. In the experience of mystical union or reunion the believer is reborn, while God saves "that which is part of him in fundamental structure." In this context, Luther's crucial understanding of the sinner's standing before God, simul iustus et peccator, becomes explicable as a simultaneous experience of mystical anguish and ecstasy.

No less provocative is Hoffman's reappraisal of what in times past were considered Luther's embarrassingly sharp sensitivities for "para-normal appearances." However, the relationship of apparitions of evil, in the form of black sows or dogs, to mysticism proper is not entirely clear. In Hoffman's account, Luther emerges as a charismatic faith healer, a sensitive psychic blessed with revelations of a "clairaudical and clairvoyant nature" who, through "the psychic force of faith," had become part of a "supernatural power field" with "access to the integrating center of the cosmos - the power center that makes cosmos one, the sun which is Christ."

This reinterpretation of Luther into a charismatic heliocentrist need not distract from the better parts of Hoffman's work. Certainly Hoffman must 
be applauded for attempting to shake ingrained preconceptions. If accepted, his findings would not only revise the traditional picture of Luther's relationship to mysticism but also force a reinterpretation on the broader historiography that has found a fruitful heuristic device in mysticism for differentiating between Luther and the radical wing of the Reformation. Unfortunately, with regard to the latter, Hoffman falls back on traditional categories. The radicals are castigated as Schwärmer appealing to subjective emotions. However, given Hoffman's own presuppositions, a distinction between true and false subjectivism becomes problematic. Hoffman appears innocent of the fact that the so-called Schwärmer were more consistent applicants of mystical assumptions to problems raised by the Reformation than Luther. ${ }^{3}$ Among the radicals was Hoffman's own namesake, Melchior Hoffman, who made it his task to publish contemporary dreams and visions. ${ }^{4}$ But what of Bengt Hoffman's contribution to the specific debate concerned with Luther's relation to medieval mysticism?

An evaluation of Hoffman's attempted revisions presupposes some knowledge of the historiographical background to the issues, issues considerably more complex than a reading of Hoffman's work suggests. Invovled are, apart from the problem of Luther's relation to the alleged Schwärmer, an assessment of (1) neo-Platonism (Augustinian or pseudoDionysian) and its significance for mystical theology; (2) variations within mysticism (transformational versus penitential); (3) the relationship between Tauler and Eckhart; (4) the nature of Luther's "reformation discovery" and its timing; (5) the relationship of Luther's evangelical insights to the major intellectual currents of his day (e.g., Augustinianism, nominalism, mysticism, the devotio moderna, humanism); and (6) the relationship of the young Luther to the mature or old Luther.

For obvious reasons an essay of this size cannot attempt to treat the issues thus indicated. Each of the questions outlined presents its own generic cluster of problems on which scholarly unanimity is not likely to be achieved by shifting the focus, as Hoffman appears to have done, to "the more primitive level of preconceptual feeling."5 The remaining part of the paper will therefore concentrate on a limited selection of contributions dealing with Luther's relationship to medieval mysticism. The intention is not to resolve but to highlight some of the remaining controversies.

Of the scholars cited by Hoffman in support of his thesis the work of Erich Vogelsang needs to be examined carefully. ${ }^{6}$ Vogelsang belonged to a group of scholars (including Emanuel Hirsch) who felt a deep affinity for the young Luther. According to Vogelsang, Melanchthon and his followers had driven transcendental intuitive feeling from Lutheran theology into secular channels. Fascinated by Luther's gropings for assurance of salvation before a just God, and interested in a soteriology that emphasized the ex- 
istential element in the process of salvation, these scholars were dissatisfied with the mere imputative formulation of justification.

Vogelsang found the leitmotif of Luther's theology in his "theology of the cross," 7 and saw its originality in the tropological exegesis of the work of Christ. The cross was for Luther no mere historical event defined by means of doctrinal exegesis demanding mental assent. It was the experience of faith. Only an internalized appropriation of Christ's humility and conformity with God's will reconciled the believer with God's righteousness and justice. ${ }^{8}$ Vogelsang found this view of justification fully developed in Luther's first lectures on the Psalms(1514). Hence there could be no question of any dependency on the mystics read by Luther after that date. ${ }^{9}$ At best, Luther discovered in Tauler a spiritual kinsman whose cross mysticism and internalization of purgatory confirmed his own experience. ${ }^{10}$ Vogelsang insisted that Luther's self-abnegation was not of mystical derivation, ${ }^{11}$ because for Luther humility was the work of God by grace alone. ${ }^{12} \mathrm{He}$ believed that Luther's dialectical view of man destroyed the psychology of the mystics in which a portion of the soul was reserved for God, and in which the connection between the human and divine had not been fully separated. Luther's tropological Christology approximated the terminology of the mystics. Like the mystics he spoke of the birth of Christ in the believer. However, according to Vogelsang, this was not, as it was for the mystics, an analogy of the trinitarian process - the birth of the uncreated Word. Indeed, everything the mystics ascribed to the "inner Word," Luther transferred to the "outer Word." Thus Luther allegedly provided an "essential" critique of all mysticism based on speculations about the unity of the ground of the soul with the essence of God. In spite of this, Luther retained a sense of the experiential presence and immediacy of God. He overcame the dichotomy between the Christ "for us" and the Christ "in us" by means of a faith union between Christ and the believer. ${ }^{13}$ Thus only in a very qualified sense does Vogelsang see Luther as indebted to the medieval mystical tradition. ${ }^{14}$

A similar appraisal of Luther's relationship at least to Tauler has been provided by Bengt Hägglund. ${ }^{15}$ Hägglund granted that, in terms of systematic anthropology, Scriptural hermeneutic, and soteriology, significant conceptual differences existed between Luther and the mystics. Not only the language but also the one-sided insistence on the inner experience and on the soul's receptivity for God separate the mystics from Luther. Yet Hägglund also discovered significant similarities. Against those scholars who had emphasized the synergistic elements in mysticism, Hägglund held that the German mystical tradition, as represented by Tauler, followed a "strict Augustinian line." Differences between Luther and Tauler, therefore, did not concern the issue of grace. Indeed, Luther found support 
in Tauler for his own views on man's passivity in the process of salvation. ${ }^{16}$ However, when stripped to these essentials, Hägglund's interpretation remains problematic.

Objections may be raised that Tauler was not part of the radical Augustinian tradition grafted onto a nominalist trunk that exerted one of the formative influences on Luther. ${ }^{17}$ Luther's contemporary, Thomas Müntzer, who according to recent scholarship was "catastrophically affected" by Tauler, ${ }^{18}$ distinguished his understanding of divine grace very clearly from Luther's "shitty humility" derived from St. Augustine. Müntzer explicitly rejected Luther's interpretation of St. Paul. ${ }^{19}$ This suggests at least the possibility that mystical influence could lead to a different understanding of the relationship of grace to human volition. When Hägglund qualified his thesis further by insisting that it was, after all, the "alien righteousness of Christ" - a concept outside the mystical system - and the emphasis on the Word as the medium of grace that constituted the key theological insight of Luther, then the significance of mysticism for Luther's development is once again left ambiguous. ${ }^{20}$

Of the recent studies probing Luther's relationship to medieval mysticism, Heiko Oberman's article is perhaps the most penetrating. ${ }^{21}$ It illustrates the complexity of the issues. Engaged in Geistesgeschichte rather than mere Lutherforschung, Oberman has been concerned primarily with portraying Luther - who in Luther research tends to become more and more a "biblical Melchisedec, without father, mother or family tree" - within the framework of the late medieval intellectual milieu. Oberman himself is rather cautious in establishing connections or dependencies and is better understood as pointing to illuminating parallels. His statements about Luther's relationship to Tauler must be viewed in the context of Oberman's larger endeavour. He has persistently stressed the significance for Luther of the Augustinian tradition in the Augustinian order, represented by men like Gregori of Rimini and Johannes von Staupitz. ${ }^{22}$ In this tradition, Gregori, a nominalist, is credited with having brought predestination from the speculative to the soteriological and Christological realms. ${ }^{23}$ Staupitz introduced Luther to St. Augustine as the interpreter of St. Paul. Both Staupitz and Luther wrestled with what Oberman considers the central problem of late medieval piety - its bondage to anthropocentric self-analysis. Luther himself, according to Oberman, as late as his Commentary of Romans (1515 / 1516) sought assurance of salvation by self-accusation. In the "theology of humility" of the late medieval period, assurance and comfort came to the sinner through a recognition of the validity of the accusation against him. Justification was thus understood as the justification of God - a recognition of the justice of God against the sinner. Staupitz and Luther allegedly solved the remaining insecurity of the sinner in "diametrically opposed" directions. Staupitz sought refuge in the righteousness of Christ, active in 
the believer. For him, the cross of Christ remained an object of meditation made effective by means of a rapture of the inner being (innerliches Ergriffensein). Luther, on the other hand, found comfort in the righteousness of Christ extra nos, and in the iustitia aliena. ${ }^{24}$ Not clear from Oberman's recent work is the timing of the discovery of the iustia aliena by Luther.

Earlier articles by Oberman suggest that he took his clue from that group of scholars intensely engaged with the young Luther. What was unique was Oberman's attempt at tracing Luther's development on a plurality of levels. ${ }^{25} \mathrm{He}$ believed it possible to stake out several successive waves or stages rather than a single major breakthrough. ${ }^{26}$ As early as $1509 / 1510$ Luther broke with one aspect of nominalism, its synthesis of reason and faith, by shifting the accent to the priority of faith. ${ }^{27}$ On another level, Luther is said to have worked out his fundamental principle of placing Scripture above tradition no later than 1512 . Within Scripture he retained the nominalist emphasis on the promises of God, the testamentum or pactum Dei in which the potentia Dei ordinata and the Gospel came together in God's oath-bound self-obligation. ${ }^{28}$ On other theological fronts, the "hardfought process of dissociation" from nominalism continued. According to Oberman, a conscious parting from nominalism occurred in 1516 in Luther's understanding of the role of human volition in the act of faith. ${ }^{29}$ He pinpointed the "decisive transition" in Luther's development as falling between his Commentaries on Psalm 113:1 and Romans 14:1. Here Luther broke with the nominalist facere quod in se est as applied to grace and free will. ${ }^{30}$ Since this break occurred during the period $(1515 / 1516)$ when Luther studied Tauler, it is tempting to conclude that a reading of Tauler influenced Luther. But what of the remaining nominalist motifs in Luther? How could nominalism be reconciled with mysticism?

The compatibility of the covenantal theology of nominalism - recognized by contemporary scholars as the characteristic feature of nominalism - with mysticism has long been disputed. Mysticism was based on the assumption of the possibility of "real" union between the human and the divine. Nominalism even more than the via antiqua shifted the attention from ontology to epistomology. Ontological and metaphysical connections between man and God were replaced by voluntary, verbal and contractual agreements. ${ }^{31}$

In his major work, Oberman argued for the compatibility of nominalism and mysticism. ${ }^{32}$ However, he found it necessary to distinguish between "transformational mysticism" and "penitential" or "affective mysticism." Transformational mysticism appeared incongruous with the covenantal nature of nominalist theology, but penitential mysticism, described by Oberman as an "essentially different type of mysticism," proved congruous. Eckhart and Tauler were numbered among those advocating a transformational mysticism. Jean Gerson, on the other hand, became a 
representative of a mysticism that could be reconciled with nominalism. Indeed, Oberman found that Gerson's mysticism was an "ideal partner" to nominalism. Gerson appeared to limit mystical union to volitional conformity with God's revealed will. Thus the mystical experience did not transcend the potentia Dei ordinata. The type of union advocated in transformational mysticism (Eckhart, Tauler) was reserved by Gerson for an eschatological event granted only to the beatified comprehensores.

According to Oberman, Gabriel Biel further "democratized" the type of mysticism congenial with nominalist thinking. The result was a kind of pneumatic piety not limited to moments of transcendental experience. A lineage could be established from Gerson to Biel to Luther. Commenting on similarities in the piety of Gerson, Staupitz and Luther, Oberman observed that with these theologians "mystical experience is no longer ... the privilege of a few elect aristocrats of the Spirit . . . ." Oberman also noted unmistakable differences among the three thinkers. For Gerson, mystical union implied the ascent of the viator ${ }^{33}$ For Staupitz, the focus shifted to the descent of Christ, while Luther was separated from both by his insistence that union with Christ was mediated through faith in God's promises. ${ }^{34}$ The question arises as to what extent Luther's emphasis on trust in the fidelity of God's promises is evidence for a continuation of nominalist assumptions in his thought.

As noted earlier, Luther parted company with the neo-Pelagianism characteristic of nominalism. Oberman's discussion of Luther's relationship to Tauler intends to illuminate this context of dissociation. Tauler aided Luther in understanding the righteousness of God as donative rather than retributive. Luther came to recognize that the righteousness of Christ and the righteousness of God come together and are granted simultaneously through faith, ${ }^{35}$ which took on mystical qualities as the medium of appropriation. It was reoriented from the scholastical fides caritate formata to the fides Christo formata. The passive and active righteousness of God merge in the appropriated righteousness of Christ. For Luther this understanding of the righteousness of God thus became the underlying premise of the life of faith. According to Oberman, the mystical concepts of gemitus, excessus mentis and raptus helped to illuminate for Luther the possibility of appropriating the righteousness of Christ "outside us." 36 Gemitus presented a welcome foil to any speculative theology of glory. By subjecting it to the overarching faith, Luther removed the synergistic elements of the scholastical conjunction of synteresis and gemitus present in the traditional theology of humility. ${ }^{37}$ Raptus pointed beyond self-righteousness and selfeffort. Luther's axiomatic simul iustus et peccator could thus be viewed as a reformulation of the mystical coincidents of opposites - simul gemitus et raptus.

None of this, however, turned Luther into a mystical theologian. Ober- 
man warned against "exaggerated assertions" about Tauler's significance for Luther. He found it important that Luther in 1516 noted parallel anthropological assumptions between Gerson and Tauler, and that he explicitly changed their terms, apex mentis and synteresis - understood by them as the highest part of the soul - to fides. Oberman traced this significant distinction back to Luther's comments on Gerson two years earlier ${ }^{38}$ Moreover, according to Oberman's schemata, Luther continued to develop his own theology well beyond 1516. In that theology, gemitus did not represent a purgatorial stage in the ascent to mystical union. It became an expression of the life of faith. Not merely grace or the preparation for grace, but the preservation of grace and the life of faith itself were for Luther the gift of God. Raptus, brought together with the extra nos, did not imply any ontological or substantive transformation in the believer but a change in affection and trust. Christ's righteousness did not become the sinner's own in the sense of a personal propety, but only in the sense of an adopted possession. Moreover, Oberman could find no traces in Luther of any mysticism advocating union with the uncreated Word, or of the mysticism using erotic bridal imagery.

To this must be added Oberman's insistence that Luther's view of the presence of Christ in Word and sacrament was contrary to the influence of late medieval mysticism as reflected in the pneumatology of the left wing of the Reformation. Luther and his movement did not stand in the tradition of "reform through inwardness" (Verinnerlichungsbewegung). ${ }^{39}$ Thus in the larger context of the Reformation, Oberman's claims of Luther's indebtedness to Tauler and to the medieval mystical tradition diminish in significance. Tauler provided little more than part of the conceptual scaffolding during a crucial stage in Luther's private development.

Oberman's qualified claims about a possible influence on Luther provided a foil to his student Steven Ozment. ${ }^{40}$ Less equivocal than Oberman, Ozment sees the "novelty" of Luther's evangelical insights in "an unprecedented, un-Augustinian merger of nominalism and mysticism." assertion, however, has to be understood against the background of $\mathrm{Oz}$ ment's deviation from Oberman's interpretation of the compatibility of nominalism with mysticism and of his greater emphasis on Luther's indebtedness to nominalism.

For Ozment, nominalism constituted a theological and philosophical counterpoint to mysticism. He believed that mystical theology specialized in the supra nos, momentary direct union with God that transcends ordinary experience. He therefore found it inappropriate to speak of a piety or spirituality adapted to nominalism as mysticism proper. ${ }^{42} \mathrm{He}$ believed that the possibility of real union between man and the divine implied a stress on immediacy, hence on the potentia Dei absoluta, in contrast to the stress on the normative secondary means, the potentia Dei ordinata, emphasized by 
nominalism. Anthropologically, mysticism stressed the common ground between the human and divine through the synteresis and union in likeness of knower and known. Thus Ozment found the "most distinctive trait" of late medieval mysticism in the affirmation that God and man share a common nature and are really connected, hence "likeness (similitudo) is the sine quo non of saving knowledge . . .."43 In nominalism, however, the conjunction of knower and known was broken. "The ascent to any higher stage . . . was cut off." 44 In this tradition the saving encounter between the individual and God did not depend on qualities within the individual (e.g. infused habits of grace) or on any "real connection between God, grace and the soul." Words, covenantal promises, the believer's trust in God's fidelity, became the channels of communication as well as the connecting links. For this reason, problems relating to the will of God and man shifted to the center of nominalist theology. In Ozment's words, nominalism became a "science of the potentia Dei ordinata" while mysticism was a "science of the potentia Dei absoluta."

By way of contrast with Oberman, Ozment stressed the mystical theology of Gerson but Luther's indebtedness to nominalism. He argued that Gerson retained a "qualified realist metaphysics which permits real contact between the soul and God." 45 The nominalist strains allegedly receded during Gerson's mystical phase. Thus, for Ozment, transformational mysticism and penitential or affective mysticism, seen by Oberman as distinctive types, have more in common with each other than either does with nominalism. Contrary to Oberman, Ozment believed that mystical union for Gerson although it did not imply an "essentialist union with God"' in which the individual lost his personal consciousness - transcended the potentia Dei ordinata to which nominalists limited all soteriological experience.

These differences of interpretation between Oberman and Ozment are carried into the respective assessments of Luther's relationship to mysticism. Oberman followed the consensus of scholars who sought Luther's break with previous teachings in his reinterpretation of the righteousness of God. Ozment, on the other hand, maintained that the bringing together of the passive and active righteousness of God in Christ by means of a tropological exegesis of the Cross was not the key novelty in Luther's theological development. Such a position did not advance beyond the solution offered by the mystics. The difference between Luther and his predecessors became evident only when Luther redefined the sinner's status before God. Mystics resolved the problem of hope and fear, built into the medieval order of salvation, by suspending the status of the sinner before God through mystical union. Luther, Ozment argued, retained the status of the viator, resolving the remaining tension between the sinner and the justified by the means of faith alone. Thus the viator retained his humanity "which he can in no way - substantially, generically or accidentally - identify either with 
God, Christ or the Holy Spirit." ${ }^{46}$ On the anthropological level, a thorough nominalist rupture with all gradualist metaphysical relations to God barred the way to union between man and God in any "real" sense. Man gained acceptance not through any transformation of his self but through faith alone. Unlike the traditional fides caritate formata, Luther's sola fide which, according to Ozment, constitutes the uncompromising difference between Luther and his predecessors - was a living and liberating faith.

By thus shifting the focus to faith alone as the distinctive element in Luther's soteriology, Ozment appears in agreement with the school of scholars who have placed Luther's theological breakthrough as coming relatively late in 1518. According to these scholars, Luther's break with medieval theological presuppositions occurred only when he linked faith with the Word of God making it the reforming principle. ${ }^{47}$ What is novel in Ozment's attempt is that he traces the beginnings of Luther's sola fide position and its implication for his view of human nature to an early dating. ${ }^{48}$ As noted above, both Hägglund and Oberman had seen in Tauler's mysticism an influence strengthening Luther's Augustinianism and aiding his struggle to free himself from the facere quod in se est of nominalism. In contrast, Ozment was struck with Luther's qualification of Tauler's anthropology the replacement of Gerson's and Tauler's usage of apex mentis and synteresis with the category of faith. According to Ozment, this constituted an "explicitly critical non-explicit criticism" by Luther of the via mystica in general. Although not all the implications were as yet evident to Luther, he had begun the redefinition of the spiritual man into a man of faith. Seen in retrospect, Luther's comments on Tauler illuminate not only Luther's dissociation from nominalism, but also his rejection of mystical presuppositions about human nature.

Ozment's findings and method of argumentation were challenged by Bengt Hoffman. According to Hoffman, Ozment was guilty of dogmatic prejudgment and the use of faulty evidence. The disputed source concerns the first sermon in the critical edition of Tauler. ${ }^{49}$ Ozment used the "outflow-inflow" theme found in this sermon to illustrate that Tauler's and Luther's view of human nature were poles apart. Hoffman believed that this particular sermon must be attributed to Meister Eckhart and not to Tauler. He concluded,

Presumably Luther never read Eckhart and presumably he therefore never saw the sermon which Ozment uses as documntation for his tenet that Luther and Tauler on deeper ground did not see eye to eye theologically. An absolutely held prejudgment, dogmatic Vorverständnis, namely that mystical theology is diametrically opposed to Luther's theology, has prevented the student of Tauler from noting that the theme on "outflow and inflow" as part of the divine "origin" is a singular occurrence in the sermon collection and that it is more Eckhartian in tone than Taulerian..$^{50}$ 
This criticism, if correct, would indeed destroy part of Ozment's supportive evidence. However, contrary to Hoffman's opinion, Luther not only read this sermon, but also commented on it. At best, Hoffman could have argued that Luther was here mistaking a sermon by Eckhart for genuine Taulerian material. It appears that Hoffman in this instance consulted neither the critical edition of Luther's works ${ }^{51}$ nor the guide prepared by Ozment in which Luther's marginal comments on Tauler are cross-listed with the texts in the critical edition of Tauler. ${ }^{52}$

Hoffman's critique of Ozment's rigid conceptualizations is of greater merit. Categories such as Catholic, Protestant, medieval, mysticism and nominalism take on the existence of medieval universals in Ozment's account. To be sure, these concepts help to sharpen issues, but none of these "ideal types" existed historically in pure form. Both mysticism and nominalism, not to mention Augustinianism, assumed diverse intellectual expressions. It is, of course, true that without some general conceptions the process of differentiation between intellectual traditions becomes difficult, if not impossible.

But what of Ozment's thesis of an "unprecedented, un-Augustinian merger of nominalism and mysticism" in Luther's thought? Ozment fails to elaborate on the mystical side of the merger. Instead, and unlike Oberman and Hägglund who have emphasized Luther's indebtedness to the Augustinian tradition, Ozment stressed the lingering influence of nominalism on Luther. Luther sought an understanding of man's position before God in light of "the promissorial nature of God's presence and the soteriologically de-substantial character of human life." He came to a "new understanding of 'congruence' between the will of man and the grace of God." Thus Ozment concluded that Luther's homo spiritualis nititur fide stands in antithesis to Tauler's concern with the ground of the soul, and to Gerson's concern with the synteresis. Ultimately Luther rejected the mystical anthropology of both Gerson and Tauler. For him, the appropriation of the righteousness of God came simultaneously with the "full recognition of man's unlikeness and opposition to God." 53

The greater emphasis by Ozment on Luther's indebtedness to nominalism contains an ironic twist to previous contentions on the subject. NeoThomists, at least since Heinrich Denifle, traced Luther's depreciation of the secondary means of grace and his misinterpretation of the mystics to an uncatholic emphasis on the potentia Dei absoluta derived from nominalism. However, scholarship has since shown that the potentia Dei ordinata was central to all nominalist theology. Indeed, Ozment has felt it necessary to warn against current exaggerated tendencies to render nominalism "fully catholic." 54 Thus while previous Luther scholarship was often on the defensive against the alleged heretical influences of nominalism, tending to stress Luther's dissociation from nominalism, Ozment maintains that "Ockham 
nonetheless remained Luther's teacher, and if a late medieval intellectual parentage of the Reformation is to be identified, Lutheranism was far more the child of Ockhamism than of German mysticism." In mysticism Luther allegedly found primarily an existential thrust, an ally against mere intellectualism. His interest lay in "features of German mysticism which, while prominent, were not distinctly mystical at all."55

In spite of these vivid assertions Ozment's conclusions remain problematic. His insistence on coupling Luther's view of human nature with the sola fide into a criterion for assessing Luther's relation to mysticism is questionable. It is tempting to argue that Ozment here took features developed later and projected them into an earlier period of Luther's intellectual struggle. Ozment apparently recognized some of the difficulties when he recently admitted that prior to 1518 Luther had not yet overcome "interior good works," and that prior to 1518 faith was still closely dependent on an interior act of humility. According to this partial retraction, exposure to Tauler aided Luther in his struggle with external-works righteousness. He overcame the more subtle internalized Pelagianism of medieval mysticism only in his post-1518 theology. In that theology, Luther coupled faith to the preached Word. ${ }^{56}$

What then can be concluded from this discussion? We have made no attempt to exhaust or resolve the problem of Luther's relationship to the medieval mystics. The aim has been to provide a sketch for the background of the historical debate. Before Luther and Tauler can be compared they must be understood in their respective historical context. The recent work by Bengt Hoffman fails on this score. He did well, however, in reminding us that Luther's fondness for Tauler is a historical fact. ${ }^{57}$ Nevertheless, the historian cannot ignore that more than a century divided the two. They stood in different traditions. Luther's explicit criticism and rejection of pseudo-Dionysius finds no parallel in Tauler. ${ }^{58}$ On the contrary, pseudoDionysius remained for Tauler an unquestionable authority of antiquity the disciple and legitimate interpreter of St. Paul. ${ }^{59}$ There is little evidence to indicate that, apart from a preference for the ancients, Tauler consciously or critically distinguished between the authorities of tradition, a point that cannot be made for Luther.

To be sure, Luther's intellectual development was stimulated, if not conditioned, by late medieval nominalism. Yet an essential element in Luther's development was his dissociation from the neo-Pelagian tendencies found in that tradition. Luther stood in the Augustinian tradition of his order, a tradition with well-developed historically critical attitudes. But Luther deviated from Augustine in his view on the crucial relationship between the Letter and Spirit, the Word and faith. No consensus exists regarding Luther's indebtedness to the medieval mystical tradition. Oberman's approach proves most congenial. It makes allowance for Luther's develop- 
ment to be examined on a variety of levels. Oberman has shown that the reading of Tauler affected Luther during a crucial turning point in his spiritual and intellectual evolution. Yet we may safely assume that Tauler had no inkling of Luther's future "evangelical insights" which functioned as a dissolvent of the higher ascetic calling that Tauler had sought to strengthen. The originality with which Luther reinterpreted the medieval theological inheritance cannot be denied. Neither ecumenical good-will nor denominational prejudice should be permitted to blur these historical realities.

Renison College, University of Waterloo

Notes

1 Luther and the Mystics (Minneapolis: Augsburg Publishing House, 1976). See also his key article, "Luther and the Mystical," Lutheran Quarterly, 26 (1974), 316-329.

2 Hoffman's repeated charges of the detrimental influence of Newtonian scientific attitudes on Lutherans need to be balanced by the interpretation that has stressed the "vitalist" orientation of Lutheranism. According to S.F. Mason, Lutheranism fed a mystical iatrochemist scientific tradition. "The Scientific Revolution and the Protestant Reformation II, Lutheranism in Relation to Iatrochemistry and the German Nature-Philosophy," Annals of Science, 9 (1953), 154-175.

3 Ronald J. Sider has reiterated the significance of mysticism for Andreas Karlstadt, "father of the radical Reformation," especially during the crucial period of dissociation from Luther. Andreas Bodenstein von Karlstadt: The Development of His Thought, 1517-1525 (Leiden, 1974), pp. 180 ff. Hans-Jürgen Goertz has come to similar conclusions regarding Thomas Müntzer in Innere und aussere Ordnung in der Theologie Thomas Müntzers (Leiden: E.J. Brill, 1967) and in "The Mystic with the Hammer: Thomas Müntzer's Theological Basis for Revolution," Mennonite Quarterly Review, 50 (1976), 83-113. See also the literature cited in $\mathrm{n} .18$ below.

4 Klaus Deppermann, Melchior Hoffman. Soziale Unruhen und apokalyptische Visionen im Zeitalter der Reformation (Göttingen: Vandenhoeck und Ruprecht, 1979).

5 See Steven Ozment's rejoinder to Hoffman in his review in The Journal of Religion, 57 (1977), 321-322.

6 See Erich Vogelsang's key articles, “Luther und die Mystik,” Lutherjahrbuch, 19 (1937), 32-54 and "Die unio mystica bei Luther," Archiv für Reformationsgeschichte, 35 (1938), 63-80.

7 The best treatment of this theme is found in Walter Loewenich, Theology of the Cross, trans. by Herbert Bowman (Minneapolis: Augsburg Publishing House, 1976).

8 For an attempt at revising Vogelsang's emphasis on conformity and his Urbild-Abbild Christologie see Horst Beintker, Die Überwinding der Anfechtung bei Luther (Berlin: Evangelische Verlagsanstalt, 1954), 156-157, 159.

9 "Dass es sich dabei nicht um Abhängigkeit Luthers von Tauler, sondern um . . . eine nachtrăgliche Bestätigung handelt, darf als sicher gelten." Vogelsang, "Luther und die Mystik," 42-43.

10 Erich Vogelsang, "Weltbild und Kreuzestheologie in den Höllenfahrtsstreitigkeiten der Reformationszeit," Archiv für Reformationsgeschichte, 37 (1940), 94-99.

11 Erich Vogelsang, "Der confessio-Begriff des jungen Luthers (1513-1522)," Lutherjahrbuch, 12 (1930), $100 \mathrm{ff}$. 
12 For a critique of Vogelsang, see Ernst Bizer, Fides ex auditu. Eine Untersuchung über die Entdeckung der Gerechtigkeit Gottes durch Martin Luther (Neukirchen: Neukirchener Verlag des Erziehungsvereins Neukirchen-Vluyn, 1958), pp. 15-22; Axel Gyllenkrok, Rechtfertigung und Heiligung in der frühen evangelischen Theologie Luthers (Uppsala: Almgrist and Wiksell, 1952), pp. 9, 17, 47-49, 80.

13 Gyllenkrok accused Vogelsang of replacing one dichotomy with another - the "for me, in me" with the communio-unio. Ibid., p.128.

14 Hoffman recognized that Vogelsang's interpretation was "swayed in different directions by the material," but he seems unaware of the larger historiographical context of Vogelsang's work. Hoffman, Luther and the Mystics, p.247 n.62, 111 ff.

15 Bengt Hăgglund, "Luther und die Mystik," in The Church, Mysticism, Sanctification and the Natural in Luther's Thought, ed. by Ivar Asheim (Philadelphia: Fortress Press, 1967), pp.84-94.

16 See also Bengt Hägglund, The Background of Luther's Doctrine of Justification in Late Medieval Theology (Philadelphia: Fortress Press, 1971), pp.9-10.

17 According to Heiko Oberman, "An Gregori von Rimini schieden sich zuerst inhaltlich und seit 1517 auch namentlich die Geister bezüglich der Legitimität einer radikal antipelagianischen Augustin-deutung und deren Verwendung im Dienst der entstehenden reformatorischen Theologie." Werden und Wertung der Reformation (Tübingen: J.C.B. Mohr, 1977), 140. Hăgglund presents no evidence that Tauler, a Thomist, or the Frankfurter, a Scotist, were under the same radical Augustinian influence.

18 This is a claim made by Gordon Rupp in "Luther: The Contemporary Image," in The Church, Mysticism, Sanctification and the Natural in Luther's Thought, ed. by Ivar Asheim (Philadelphia: Fortress Press, 1967), 15. To the literature dealing with mysticism and the radical Reformation cited in n. 3 above, should be added: Steven Ozment, Mysticism and Dissent. Religious Ideology and Social Protest in the Sixteenth Century (New Haven, London: Yale University Press, 1973); G.H. Williams, "Popularized German Mysticism as a Factor in the Rise of Anabaptist Communism," in Glaube, Geist, Geschichte: Festgabe für Ernst Benz, ed. by G. Mueller and W. Zeller (Leiden: E.J. Brill, 1967), 290-312, and "German Mysticism in the Polarization of Ethical Behaviour in Luther and the Anabaptists," Mennonite Quarterly Review, 48 (1975), 275-304; Werner O. Packull, Mysticism and the Early South GermanAustrian Anabaptist Movement 1525-1531 (Scottdale, Pennsylvania: Herald Press, 1977).

19 Thomas Müntzer, Thomas Müntzer. Schriften und Briefe, ed. by Günther Franz (Gütersloh: Gütersloher Verlaghaus Gerd Mohn, 1968), 339.

20 Hăgglund, Background of Luther's Doctrine of Justification in Late Medieval Theology, 15-16, 34.

21 "Simul Gemitus et Raptus: Luther und die Mystik," in The Church, Mysticism, Sanctification and the Natural in Luther's Thought, ed. by Ivar Asheim (Philadelphia: Fortress Press, 1967), 20-59.

22 Oberman, Werden und Wertung der Reformation, esp. the chapter, "Augustinrenaissance im spăten Mittelalter," 82-140; also "Headwaters of the Reformation: Initial Lutheri - Initia Reformationis," in Luther and the Dawn of the Modern Era, ed. by Heiko Oberman (Leiden: E.J. Brill, 1974), 78-79. Leif Grane has challenged the evidence for an early influence by Gregori in "Lutherforschung und Geistesgeschichte. Auseinandersetzung mit Heiko A. Oberman,"Archiv für Reformationsgeschichte, 68 (1977), 101-103.

23 The emphasis on the anti-speculative nature of nominalism and its experienta orientation is a hallmark of Oberman's debate with Catholic historians. It is the thesis of his book, The Harvest of Medieval Theology (Grand Rapids, Michigan: Wm. B. Eerdman, 1967); see also his Werden und Wertung der Reformation, pp. 6-7, esp. chap. 3; also "Reformation: Epoche oder Episode?" Archiv für Reformationsgeschichte, 68 (1977), 98, n.93; and "Contra vanam curiositatem. Ein Kapitel der Theologie zwischen Seelenwinkel und Weltall," Theologische Studien, 113 (1974), 38, 44.

24 Oberman, Werden und Wertung der Reformation, pp.89, 98, 108-110, 112-113. It is not entirely clear whether Oberman is in total agreement with Karl-Heinz zur Muhlen whom he cites approvingly. Nos Extra Nos. Luthers Theologie zwischen Mystik und Scholastik (Tübingen: J.C.B. Mohr, 1972). 


\section{2 / Renaissance and Reformation}

25 Oberman's approach has been criticized by Leif Grane as "orbiting" around Luther rather than penetrating his development. For the exchange see Oberman, "Reformation: Epoche oder Episode?" esp. 88-109, and Grane, "Lutherforschung und Geistesgeschichte. Auseinandersetzung mit Heiko Oberman," 302-315.

26 "Facientibus quod in se est Deus non denegat gratiam. Robert Holcot, O.P. and the Beginnings of Luther's Theology," The Harvard Theological Review, 55 (1962), 317-342, esp. 338.

27 Ibid., pp. 333, 340. Lawrence Murphy, on a somewhat different level, has traced an "advance toward the dawning of reformation consciousness" to Luther's separation of philosophy and theology as early as 1509. Murphy, "The Prologue of Martin Luther to the Sentences of Peter Lombard (1509): The Clash of Philosophy and Theology," Archiv für Reformationsgeschichte, 68 (1976), 54-75.

28 Oberman, "Contra vanam curiositatem," pp.51-52; also "Reformation: Epoche oder Episode?’ p.81 n.58.

29 Oberman, "Headwaters of the Reformation: Initia Lutheri - Initia Reformationis," p.67.

30 Oberman, "Facientibus quod in se est Deus non denegat gratiam," 338.

31 For an updated discussion on the main features of nominalism see William Courtenay, "Nominalism and Late Medieval Religion," in The Pursuit of Holiness in Late Medieval and Renaissance Religion, ed. by C. Trinkaus and H. Oberman (Leiden: E.J. Brill, 1974), 26-59, esp. 51; see also the five point summary by Oberman, "The Shape of Late Medieval Thought: The Birthpangs of the Modern Era," ibid., 3-25, esp. 13-15.

32 Oberman, Harvest of Medieval Theology, pp. 327-360.

33 Walter Dress contrasted Gerson's gradus-Schema and its synergism to Luther's totus homo Begriff in his article, "Gerson und Luther," Zeitschrift für Kirchengeschichte, 52 (1933), 122-161.

34 Oberman, "The Shape of Late Medieval Thought: The Birthpangs of the Modern Era," pp.19, 23. On Staupitz see the works by David Steinmetz, Misericordia Dei. The Theology of Johannes von Staupitz in its Late Medieval Setting (Leiden: E.J. Brill, 1968); Luther and Staupitz. An Essay in Intellectual Origins of the Protestant Reformation (Durham: Duke University Press, 1980); " Religious Ecstasy in Staupitz and the Young Luther," The Sixteenth Century Journal, 11 (1980), 23-37.

35 Heiko Oberman, “' 'Iustia Christi' und 'iustia Dei'. Luther und die scholastischen Lehren der Rechtfertigung," in Der Durchbruch der reformatorischen Erkenntnis bei Luther, ed. by Bernhard Lohse (Darmstadt: Wissenschaftliche Buchgesellschaft, 1968), pp.436, 438-442. It appears that Oberman attributed to Luther a Mittlerchristologie at this time.

36 Oberman, "Simul Gemitus et Raptus: Luther und die Mystik," p.110.

37 David Steinmetz has argued that for Luther religious ecstasy is possible not because of synteresis or any process of self-discipline and self-denial, but by faith alone. Thus, however, Luther "has begun to redefine all the traditional concepts - including the language of mystical theology - in the light of his new understanding of the meaning of faith." "Religious Ecstasy in Staupitz and the Young Luther," 37.

38 Oberman, "Simul Gemitus et Raptus: Luther und die Mystik," p.33. In his "Contra vanam curiositatem" (p.49), Oberman makes the point that Luther criticized Gerson because the mystical experience advocated by him superceeded the experience of sola fide. In "Simul Gemitus et Raptus: Luther und die Mystik"' (p.37), however, Oberman suggests that Luther did not really censure Gerson. He only warned "later on" that mystical experiences are dangerous and can be a trick of the devil.

39 Oberman, "Headwaters of the Reformation: Initia Lutheri - Initia Reformationis," p.67; "Contra vanam curiositatem," p.51.

40 Homo Spiritualis. A Comparative Study of the Anthropology of Johannes Tauler, Jean Gerson and Martin Luther in the Context of their Theological Thought (Leiden: E.J. Brill, 1969).

41 "Mysticism, Nominalism and Dissent," in The Pursuit of Holiness in Late Medieval and Renaissance Religion, ed. by C. Trinkaus and H. Oberman (Leiden: E.J. Brill, 1974), pp.26-59.

42 Ibid., p.71: ". . . until the potentia ordinata is transcended, it can be argued that there is, properly speaking, no mysticism." 
43 Ibid., pp.71, 72 n.4, 73, 77. Zur Muhlen in a more qualified way has made a similar point when he argues that in mystical thought salvation was inconceivable without attributing some soteriological quality to human nature. Nos Extra Nos, p.97.

44 This is also a point made in the article by Edward Cranz, "Cusanus, Luther and the Mystical Tradition," in The Pursuit of Holiness in Late Medieval and Renaissance Religion ed. by C. Trinkaus and H. Oberman (Leiden: E.J. Brill), pp.93-102, esp. p.95.

45 Ozment concluded, "Gerson, then, preserves the distance between God and man in the mystical union. But it is a distance and otherness of two generic 'likes.' The radical opposition between a righteous God and a sinful man disappears in the union of likes." Homo Spiritualis, p.83.

46 Steven Ozment, "Homo Viator: Luther and Late Medieval Theology," in The Reformation in Medieval Perspective, ed. by Steven Ozment (Chicago: Quadrangle Books, 1971), pp.150-152.

47 Perhaps the best representative of this school is Ernst Bizer, Fides ex auditu. For a listing of other important authors who are in agreement with Bizer, see Kenneth Hagen, "Changes in the Understanding of Luther; the development of the young Luther," Theological Studies, 29 (1968), 472-496; Otto Pesch, "Zur Frage nach Luthers reformatorischer Wende. Ergebnisse und Probleme der Diskussion um Ernst Bizer, Fides ex auditu," in Der Durchbruch der reformatorischen Erkenntnis bei Luther, ed. by Bernhard Lohse (Darmstadt: Wissenschaftliche Buchgesellschaft, 1968), pp.445-505.

48 It is noteworthy that Ozment in his earlier works sided with critics of Bizer even though his focus on the significance of faith corresponds more closely with the emphasis of Bizer. Ozment, Homo Spiritualis, p.215 n.2.

49 Ferdinand Vetter, Die Predigten Taulers (Dublin, Zürich: 1968). Hoffman used the high German translation by G. Hofmann, Johannes Tauler Predigten. Vollständige Ausgabe (Freiburg: Herder, 1961).

50 Hoffman, Luther and the Mystics, p.95.

51 D. Martin Luther Werke. Kritische Gesamtausgabe, IX (Weimar Edition, Weimar, 1893), p.95.

52 Steven Ozment, “An Aid to Luther's Marginal Comments on Johannes Tauler's Sermons," in Harvard Theological Review, 63 (1970), 305-311. Hoffman's mention of the 1498 Leipzig edition seems irrelevant apart from the fact that Luther's notes on Tauler appear in the margins of a reprint, the 1508 Augsburg edition. (Later at the Wartburg, Luther used the 1521 / 1522 Basel editions.) The source in question appears as the first sermon in both of these publications. It is also the first sermon in the critical edition of Tauler's sermons by Vetter. Hoffman was, of course, correct in questioning its authenticity. Of the eighty-three sermons attributed to Tauler in the Augsburg edition, five (numbers 1, 8, 9, 78 and 82) are under dispute. Of the sermons commented on by Luther, only number 9 is not found in the critical edition of Tauler. It appears instead as number 3 in Pfeiffer's edition of Eckhart's sermons. As for the authorship of the first sermon found in the critical edition of Tauler, no scholarly census exists, although recent scholarship has argued for its authenticity. Only sermon numbers 59 and 79 found in the critical edition of Tauler have been clearly identified as not Taulerian. In spite of its shortcomings therefore, the critical edition of Tauler by Vetter remains the best for scholarly purposes. Peter Erb has provided a helpful listing of Eckhart's sermons appearing in the 1508, 1522, 1621 and 1703 editions of Tauler. "The Role of Late Medieval Spirituality in the Life and Work of Gottfried Arnold (1666-1714)" (unpublished Ph.D. dissertation, University of Toronto, 1976), esp. pp.536-546. The dissertation was made available by the courtesy of Dr. Erb.

53 Ozment, Homo Spiritualis, pp. 165-166, 214-215.

54 Ozment, "Mysticism, Nominalism and Dissent," p.80.

55 Steven Ozment, "Eckhart and Luther: German Mysticism and Protestantism," The Thomist, 42 (1978), 259-280, esp. p.269.

56 Ibid., pp.267-269.

57 Bernd Moeller lists the number of times Luther mentioned Tauler in "Tauler und Luther," in La mystique Rhénane: Colloque de Strasbourg, 16-19 Mai, 1961 (Paris, 1963).

58 D. Martin Luther Werke. Kristische Gesamtausgabe, V (Weimar Edition), p.163.

59 For the conjunction of Dionysius and St. Paul in Tauler see Vetter, Die Predigten Taulers, pp.174, 190, 351, 411 . 